\title{
Comparative Analysis of Earnings Rate, Retention Rate, and Dividend Yield as Determinants of Capital Growth
}

\author{
Daibi W. Dagogo ${ }^{1} \&$ Lawyer C. Obara ${ }^{2}$ \\ ${ }^{1}$ Department of Banking and Finance, Rivers State University of Science and Technology, Port Harcourt, \\ Nigeria \\ 2 Department of Accountancy, Rivers State University of Science and Technology, Port Harcourt, Nigeria \\ Correspondence: Daibi W. Dagogo, Department of Banking and Finance, Rivers State University of Science and \\ Technology, Port Harcourt, Nigeria. Tel: 234-803-405-4408. E-mail: dagogo.daibi@ust.edu.ng
}

Received: October 8, 2014

doi:10.5539/ijef.v7n2p214
Online Published: January 25, 2015

URL: http://dx.doi.org/10.5539/ijef.v7n2p214

\begin{abstract}
This work compares the effect of earnings rate, retention rate, and dividend yield on the capital growth of Nigeria's emerging and large companies. The study begins with a detailed characterization of emerging companies in the Nigerian context, then, an extensive review of both theoretical and empirical studies surrounding dividend policy. Thereafter, three contextual arguments or positions were identified to provide the framework for divergence or convergence with the outcome of this work. The variables were also specified as follows: growth in equity capital (GEC), earnings rate (ER), retention rate (RR), and dividend yield (DY). Two procedures were adopted: $\mathrm{z}$-test of two means, aimed at providing additional basis for predicting the outcome of our estimates. To do this, ten years time series data were collected from the annual financial reports of ten emerging and twenty large companies quoted on the Nigeria Stock Exchange, thus, pooling 100 data items for emerging companies and 200 data items for large companies. Then, the means of the respective variables for each size of company were compared, particularly, to establish any significant growth pattern explained later in the second procedure. The second procedure involves specification of panel data regression model with random effect, one for each of the two classes of companies. The results show statistically significant and consistent differences between the two categories of companies in the means of GEC and ER. Secondly, for the emerging companies, only RR significantly contributed to changes in GEC. Thirdly, for the large companies, none of the independent variables significantly explained changes in GEC. It was concluded that the study did not demonstrate any pattern in dividend/retention behavior in emerging or large companies that is consistent with any of dividend policy positions, leading us to conclude that no single dividend policy magic wand is a recipe for all managers at all times.
\end{abstract}

Keywords: dividend, retention, capital growth, emerging companies, dividend yield

\section{Introduction}

\subsection{Background of Study}

The idea of starting, growing and sustaining a business up to the initial public offer sounds very appealing to many discerning entrepreneurs but in reality only one of twenty-five start-ups lives to tell that zero-to-IPO story (Smith, 2013). For a country like Nigeria, this story is even hardly told in the real sector as the business environment can hardly boost of a winning formula to deal with deficient building blocks and insensitive government policies. So, businesses have had to fend for themselves in almost every infrastructure such as electricity, water, good roads, communication, education, training, etc. This has had huge and regularly acknowledged effect on the overall competitiveness of Nigerian products in the international market, first with respect to price, and second with correspondingly adverse effect on foreign direct investment and greater motivation toward capital repatriation (Groh \& Liechtenstein, 2012). While all of these have caused untold hardship on business survival in Nigeria, it has opened up opportunities for other emerging economies to expand their markets into Nigeria's import-oriented consumer society with expanding demand capacity that is the result of phenomenal growth in middle class (Stein, 2001; Stiglitz, 2002; Dagogo, 2014).

Recent events have however turned Nigerian economic outlook into an alternative investment destination as the 
nation peps up investments in ICT, agriculture and power sectors, along with reforms in Ports, investment laws, and education (Dagogo, 2012). The implication of the emerging status is increasing GDP per capita arising from stronger business resistance to collapse, greater potential to grow, ability to compete in international markets, and ease of transformation to large enterprises (Abdou \& Moshiri, 2012). Similarly, Dagogo (2006) identified six basic indicators that are instrumental to enterprise development: sales, profit, employment, economic value added, technology and capital. This study takes keen interest in internal capital as an instrument to grow emerging companies.

Literally, retained earnings and dividend represent two sides of a coin that may just be a conceptual misfit as it is assumed that both sides of the coin must be equal for each to be on one side of the coin. In reality and indeed what had been the puzzle in finance is the rare equality between retained earnings and dividend, and the overarching implication of the foregoing. That is, even if there is a coincidental equality in the nominal sense, there is never going to be any equality in the implicit sense of it. Again the subject matter of this paper borders on two key decision areas in finance: first, retained profit is part of equity capital, and second, retention is a deprivation of shareholders' dividend. In other words, the retention-dividend dilemma affects the firm either as part of financing decision or as part of dividend decision. This is not to suggest any irrelevance of dividend policy position but rather to say, for instance, that a cup that is two-thirds full is also one-third empty.

Emerging companies are high-potential high-growth enterprises that are upward mobile in terms of sales, profit, capital, employment, and technology. They are companies that are at the threshold of becoming large enterprises. Others are listed in the alternative investment markets of the Nigerian stock exchange. There are also private companies in this category that are piloted by private equity firms and operated in the over-the-counter (OTC) market that may not necessarily be high-technology companies. In Nigeria, the Private Companies Conversion and Listing Bill (2013), permits emerging companies with over N40 billion in share holding or N80 billion in annual revenue or N80 billion in total assets to convert to public companies. The alternative investment market is the NASDAQ-typed securities market for upcoming firms. This market provides liquidity for investors and accentuates equity culture among Nigerians.

\subsection{Relevant Theories}

Dividend decision affects both profit and capital gains of shareholders. It also represents capital lost to the manager who regularly wishes shareholders to retain their earnings to finance future investment projects and therefore spares him the risk of borrowing or the challenge of meeting higher rate of return over cost (RROC). To that extent, the shareholder's gains (dividend) is the manager's loss (retained capital). A diligent review of dividend policy clearly identifies three key intellectually difficult-to-dissolve thoughts: first, high dividends increase market value because dividends are more certain than capital gains as the maxim says $a$ bird in hand is worth more than a thousand in the bush (Lintner, 1956; Walter, 1956; Gordon, 1959). Second, it is not higher dividends but lower dividends that actually increase market value, as higher dividends reduce stock prices because taxable investors pay higher taxes on dividends than on capital gains (Brealey, 1981; Keown et al., 1997; Pandey, 2005). And third, dividend policy does not matter as investors care only about their total returns and the level of total shareholders returns is unaffected by management decision to pay out part of that return as dividends (Miller \& Modigliani, 1961; Miller \& Scholes, 1978).

The pursuit of these three positions have introduced so much intrigue, advanced significant arguments and provided volumes of essays to unravel the dividend puzzle. Besides, the intellectual exercises that these three positions have thrown open, and the process of improving our thinking have led to the emergence of several extensions of the traditional thoughts. They include the residual dividend theory, that is, dividend decision is a mere passive decision as it comes after all acceptable investments opportunities have been financed, and to that effect, it has no direct influence on the market price of shares (Myers, 1984). Next is the information effect, which demonstrates how investors can use dividend to solve the problem of information asymmetry. The proponents of this thought (Watts 1973; Bhattacharya, 1979) observed that since management would often not divulge significant internal information about the company's prospects, investors are only left with the sensitivity to dividend payments to predict the performance of management in a world of perfect market. Another area that has equally attracted researches is clientele effect, which explains how firms attract a particular clientele of investors, given their stated dividend policy and that if investors do have preferences between dividends and capital gains, they would have a dividend policy that would be consistent with these preferences, that is to say, they would sort themselves out by buying shares that satisfy their preferences for dividends and capital gains (Miller \& Modigliani, 1961; Lease et al., 1976). However, Keown et al. (1998) states that the possibility that clientele of investors exists might create a chance to believe that dividend policy matters, but this requires a greater aggregate demand for a particular policy than the market can satisfy. Otherwise, dividend policy remains 
unimportant as one policy is as good as the other.

Another variant that has developed is the expectation theory, which draws from the rest of the other thoughts. This theory anchors on the fact that markets respond not only to management's ultimate action but also to investors' expectations of the ultimate decision by management. These expectations are determined by internal factors such as past dividend decisions, current earnings, investment strategies and financing decisions, and external factors such as the general economic condition, factors specific to the industry, and changes in government policies (Keown et al., 1998). Other extensions include agency cost and earnings theories clearly discussed in Jenson-Meckling (1976), Ross (1977), Rozeff (1982), Copeland-Weston (1988), and Kinkki (2001).

\subsection{Empirical Evidence from Nigeria}

The issue of dividend became a prominent academic exercise in Nigerian with the work of Uzoaga and Alazienwa (1974) which examined the pattern of dividend policies of Nigerian firms in the era of nationalization of foreign firms. The study found insignificant evidence to support the bird-in-hand classic. Although the work was critiqued on grounds of inclusion of irrelevant determinants, timing bias and inappropriate evaluation techniques, Oyejide (1976) affirmed Uzoaga's study and concluded that the available evidence provided a strong and unequivocal support for the classical position among Nigerian corporations. Nyong (1990) also used similar parameters to conclude that the conventional Lintner's model performed too well in asserting the classical argument of dividend relevance.

Adelogun (2001) showed that multinational companies operating in Nigeria pay out proportionately more dividend than wholly Nigerian-owned companies. Also, Adesola and Okwong (2009) adopted Lintner's (1956) partial adjustment model, as modified by Charitou and Vafaes (1998) and Brittain (1964) to identify the factors that influence dividend policy of a cross section of Nigerian quoted firms between 1996 and 2006. They found that average earnings per share (EPS) is the most significant determinant of dividend policy, that growth prospect and firm size have no significant impact on dividend policy of quoted firms, that current dividend and earnings are significant in explaining the observed differences in share prices, that EPS has greater magnitude than dividend policy on share price, and that Nigerian market capitalizes the estimates of cash flows receivable by shareholders as dividend therefore market price of shares is a representation of market valuation of dividend. Other empirical results were from Musa (2009) on the impact of dividend policies variations on quoted firms, and Adediran and Alade (2013) on the effect of dividend policies on profitability, investments and EPS. Surprisingly, most of the studies were centered on share price or valuation effect.

This work is therefore a departure from previous empirical works in Nigeria as it studies growth pattern of equity (a direct, tangible and explicit variable) resulting from retention rate, dividend yield and earnings rate. Secondly, it is a comparative analysis which divorces emerging companies from mainstream companies in order to characterize their respective responses. Accordingly, the following questions have been crafted to guide the research: To what extent do earnings rate, retention rate and dividend yield contribute to capital growth? And, are there significant differences in these contributions between emerging and large companies in Nigeria?

\subsection{The Arguments}

The manner of inquiring into the dividend puzzle involves two paths. First is to say that a policy of paying dividend truly affects corporate growth. Second is to admit that it does not affect corporate growth. Perhaps the easier to comprehend, more explicit, and logically less involving of the two is the first option. It is a simple accounting and arithmetic procedure only requiring the extension of the earnings model or the dividend growth model to show that every unit of Naira retained represents an opportunity cost, equivalent to equity capitalization rate, which must be adequately compensated (Olowe, 2008; Musa, 2009). This gives rise to three versions of the first argument: in order to receive an optimal effect of dividend policy on corporate growth, should none, more or less be paid? Recall that the inverse of this question will be: should all, less or more be retained? If all were retained, then the explicit return to shareholders is zero while managers capitalize one hundred percent of the earnings for future investments proposal at an opportunity cost that will permit managers to accept cost-competitive projects.

The second strand, dividend is irrelevant as it is not instrumental to growth of emerging companies, was the position of Miller-Modigliani (MM) in their 1961 argument that corporations should pay all earnings as dividend, as there is no need for dividend decision because it does not affect the value of the firm. This goes beyond a mere accounting procedure to the use of implicit model to estimate the effect of dividend policy on market value. MM (1961) argued that given the investment decision of the firm, dividend decisions are mere details as they do not affect the value of the firm and by extension shareholders' value. For them, the value of the firm is determined by the earnings power of the firm's assets or investment policy. The manner in which the earnings 
stream is split between retained earnings and dividend does not affect the value. They claimed that the effect of dividend payments on shareholder's wealth (in a world without tax) is directly offset by other means of financing. Miller and Scholes (1978) also proved the same in a world of tax.

Closely looking at the question (should more or less be retained?), another arguable proposition emerges. If we take a position of relevance of dividend policy to the effect that 'more' dividends translate to 'less' earnings capitalization and vice versa, it means that higher dividend reduces opportunity to finance future projects and so reduces growth. But that is from the manager's view point. Who says the shareholders do not want growth? They do but they would prefer a 'homemade' growth, and to leave the manager to source external funds for corporate growth. So they say a bird in hand is worth more than a thousand in the bush. As Black (1976) commented, the harder we look at the dividend picture, the more it seems like a puzzle, with pieces that just do not fit together. Just as having homemade growth does not fit with paying dividend in a growth-bound emerging company.

No topic has attracted so much attention as that of the relationship between dividend policy and market value of shares. Most of these fundamental analyses rested on the assumption that the changing intrinsic value of shares is a function of earnings, dividends, capital structure or growth potential (Kinkki, 1997). Not many specific empirical studies are available on the determinants of dividend payout or retention in emerging companies. To digress a bit, we observe that in the private equity asset class, studies show the return of private equity investment is J-curved, an acceptable symbol to reflect the general behavior of private equity returns that in reality hardly expresses the true behavior of private equity returns (Fraser-Sampson, 2010). The message from $\mathrm{J}$-curve is that private equity investors are not in haste to receive returns from their investment, as annual returns are capitalized particularly at the firm's early stage. This of course characterizes private equity as a distinct asset class in terms of its risk-return configuration. The essence of this digression is to liken emerging companies to the private equity-backed firms and to expect some resemblance in their behaviors with respect to equity financing and profit retention. With private equity, return is a one-stop shop which encompasses expected dividends for an upward of four years, expected growths over the same period, the opportunity cost of capitalizing shareholders' dividends and foregoing capital gains (Dagogo, 2009; Fraser-Sampson, 2010). They sum up to justify the multiple earnings of private equity investors. For emerging companies, the dilemma of postponing dividends and for sacrificing capital gains may not be precisely articulated but rather left to the vagaries of the market.

Another difference derives from the fact that private equity firms are driven by venture capitalists or business angels while the securities of emerging companies are traded in the alternative investment market, and are therefore bound to comply with additional statutory regulations with respect to dividend payments. Clearly, not paying dividend might send negative signals to the market (Keown et al., 1998). The fact that emerging companies are restricted public companies presupposes that once upon a time they were private equity-driven. Although it is not the issue at stake here, one may curiously wish to know if enterprise development continuum follows the pecking order that prescribes private equity for start-up and early growth, bridge (medium term debt) finance for later growth, initial public offer for expansion and stability, and debentures or other long term instruments (debt or equity) for strategic growth (Myers, 1984). A fair guess is to place these emerging companies on the post-IPO rung of the continuum, and that means they compare with large companies on the main list of the Nigeria Stock exchange with respect to financing yet they do not enjoy the same visibility as the large companies which are likely to crowd out available private sector investment funds. Accordingly, they must turn first to internal capital and exhaust what there is before looking elsewhere, but if they do so for too long, it sends a wrong signal as argued by the information asymmetry theorists.

Finally, if one conjectures that the desire to grow preoccupies the strategic plans of both categories of companies, their dividend policies are bound to reflect their propensity to grow. However, emerging companies have less visibility to obtain funds than large companies, yet they are not strictly private equity-backed. Assume that dividend matters, and all other factors held constant, we expect to observe significant differences between their retention rates, dividend yields, and earnings capitalization rates

\subsection{Definition of Variables}

This section offers academic meanings that justify the relevance of the variables in the study.

\section{(a) Growth in Equity Capital}

In this study, growth refers to the sustainable physical increments in market, profit, and capital engineered by business leaders' relentless pursuit of opportunity and innovation (Sahlman, 1987; Charan \& Tichy, 1998). More specifically, the study is about growth that is centered on capital efficiency, as growth-bound emerging companies are normally expected to roll back part of their earnings to finance investment opportunities to 
support growth. So, the issue is whether or not we accept the irrelevance of dividend policy position as succinctly and logically demonstrated by Miller and Modigliani (1961) and Miller and Scholes (1982), there is an implication for growth of emerging companies. Academic and empirical works have created at least three critical mindsets in the manner of maximizing shareholders' wealth. But here, we refer to growth that is tied to capital. To that extent we will not freely assume the many-ways-to-skin-the-cat approach as worthwhile because there must be an optimal choice that leaves more money in the pocket of the shareholders.

\section{(b) Earnings Rate}

Generally, earnings rate (ER) is the opportunity cost of fund upon which investors are willing to commit their funds and below which they are unwilling. It measures a company's earnings per share (EPS) as a percentage of its share price. The higher the rate, the higher is the earning generated per Naira of share price. It shows the expected rate upon which future investments must be accepted in order to maintain the net present value (NPV) of shareholders. It is the inverse of price/earnings $(\mathrm{P} / \mathrm{E})$ ratio. Earnings rate is used to determine fair value of a share in a perfect market. It is also a measure of expected (not realized) growth. It is calculated as a measure at which investors will capitalize a firm's earnings in the coming period. Behaviorally, when earnings rate is high, shareholders are tempted to retain more capital than when it is low. So with higher earnings rate, we expect higher capital growth.

\section{(c) Retention Rate}

Retention rate is simply the proportion of capitalized earnings expressed in percentage. Its inverse is the dividend payout rate. This follows that as part of the financial decisions, managers have to trade-off between high and low retention rates, large and small dividend, as well as heavy and light external equity financing. Each of these decisions has direct effect on shareholders' wealth and that has sparked off lots of essays in the dividend debate. This work shows that for emerging companies whose return to shareholders should reflect the J-curve prevalent in private equity firms, retention rate is a strong determinant of growth from the simple logic of having to capitalize retained earnings at a far less opportunity cost than external capital. (Emekekwue, 2005; Dagogo, 2009).

\section{(d) Dividend Yield}

Dividend yield (DY) is a measure of how much cash flow one receives from each Naira invested in an equity position. For investors with minimum benchmark or expected stream of cash flow, dividend yield of a given share shows if a given share is efficient with respect to its yield. DY equals annual dividend per share divided by price per share. It is actually the dividend/price ratio, and its inverse is the price/dividend (P/D) ratio, which will show how many times an investor may earn a given dividend at a given price to breakeven. DY ratio measures the relative efficiency of a share.

With the baseline of Nigeria's business environment forwarded above, the implications of the three dividend policy positions in the thought processes of investors reviewed, and the three variables hypothesized as determinants of capital growth clearly defined, this paper is set to compare the effect of retention rate, earnings rate and dividend policy on capital growth of emerging and large companies. This involves two statistical procedures: test of two means and estimation of panel data regression models.

\section{Method}

\subsection{Collection of Data}

Ten years time series data relating to the variables studied were collected from the annual financial reports of ten emerging and twenty large companies quoted on the Nigeria Stock Exchange. The variables were determined as follows: growth in capital equals annual total equity capital; retention rate equals (earnings - dividend paid out)/ earnings; earnings rate equals earnings/total equity capital; and dividend yield equals dividend/ total equity capital.

\subsection{Test of Two-Sample Means}

The first procedure entails test of two-sample means from different populations involving the two categories of companies compared. Available data covering both dependent and independent variables for emerging and large companies were compared to ascertain any significant differences in the following variables: total equity capital (the proxy for growth), retention rate, dividend yield, and earnings rate. To do this, time series data from 2003 to 2012 were pooled alongside cross sectional data of ten emerging companies and twenty large companies, which presented 100 and 200 units of data respectively for each variable. This makes for a robust analysis and eliminates errors associated with data at annual, biennial or quadrennial intervals. The test statistic for this 
method is z-test, which is of the form

$$
Z_{\bar{X}_{1}-\bar{X}_{2}}=\left\{\left(\bar{X}_{1}-\bar{X}_{2}\right)-\left(\mu_{1}-\mu_{2}\right)\right\} / \sigma\left(\overline{x_{1}}-\overline{x_{2}}\right)
$$

Where $\bar{X}_{1}$ equals sample mean of emerging companies, $\bar{X}_{2}$ equals sample mean of large companies, $\mu_{1}$ equals population mean of emerging companies, and $\mu_{2}$ equals the population mean of large companies. Since $X_{1} \sim N\left(\mu_{1}, \sigma_{1}^{2}\right)$ and $X_{2} \sim N\left(\mu_{2}, \sigma_{2}^{2}\right)$, then $\bar{X}_{1}-\bar{X}_{2} \sim N\left[\left(\mu_{1}-\mu_{2}\right), \frac{\sigma_{1}^{2}}{n_{1}}+\frac{\sigma_{2}^{2}}{n_{1}}\right]$, where $N$ is the population (Cooper \& Schlinder, 2001; Paneerselvam, 2013). Furthermore, the nature of data of retention rate and dividend yield suggests the application of test of means of proportion. For these data, the test tool is of the form

$$
Z_{\bar{p}_{1}-\bar{p}_{2}}=\left(\bar{p}_{1}-\bar{p}_{2}\right)-\left(\mu_{1}-\mu_{2}\right) / \sigma\left(\bar{p}_{1}-\bar{p}_{2}\right)
$$

Where $\sigma\left(\bar{p}_{1}-\bar{p}_{2}\right)=\sqrt{p_{1}\left(1-p_{1}\right) / n_{1}}+p_{2}\left(1-p_{2}\right)$. Again, z-test is appropriate because with large proportion, such as this, the binomial distribution is approximated to normal distribution i.e. $\mathrm{X} \sim N\left(\mu, \sigma^{2}\right)$.

\subsection{Panel Data Regression Model with Random Effect}

The second procedure involves estimation of panel data regression models for emerging and large companies and the analysis of the comparison of the strength of the coefficients to explain changes in the dependent variables. Ten years time series data were collected for each of the variables relating to emerging and large companies. Cross-sectional data were also collected for each variable relating to ten emerging and twenty large companies. This suggested a ten-by-ten panel data model for emerging companies and ten-by-twenty panel data model for large companies. This technique did not only pool both time series and cross-sectional effects in order to increase the efficiency of the models but it also reduces the usual problems of time series data and cross sectional data when taken independently. These problems include multi-collinearity, autocorrelation, and heterogeneity. This technique also allows more degree of freedom thus minimizing aggregation bias and providing more reliable estimates (Koutsoyiannis, 2001; Gujarati \& Sangeetha, 2007). The models are of the form:

$$
\begin{gathered}
G E C_{i t}^{E C}=\beta_{1}+\beta_{2} E R_{2 i t}+\beta_{3} R R_{3 i t}+\beta_{4} D Y_{4 i t}+U_{i t} \\
G E C_{i t}^{L C}=\beta_{1}+\beta_{2} E R_{2 i t}+\beta_{3} R R_{3 i t}+\beta_{4} D Y_{4 i t}+U_{i t}
\end{gathered}
$$

Where $G E C$ equals growth in total equity, $\beta_{1}$ equals the intercept of the $Y$-axis; $\beta_{2}, \beta_{3}$ and $\beta_{4}$ are the parameter of the independent variables; $E R$ : equals earnings rate; $R R$ : equals retention rate; $D Y$ : equals dividend yield; $i$ equals the $1^{\text {st }} 2^{\text {nd }}, 3^{\text {rd }} \ldots 10^{\text {th }}$ cross-sectional unit for equation (3) and $20^{\text {th }}$ cross-sectional unit for equation (4); $t$ equals 2003, 2004, 2005, .. 2012 for equations (3) and (4); and $U_{i t}$ equals the combined time series and cross section error component.

More specifically, the error component model (ECM) was adopted here as it is intended to express absence of certain information in the study through the disturbance term $\mu_{i t}$ instead of creating dummy variables that lead to losses of the number of degree of freedom (Gujarati \& Sangeetha, 2007). Accordingly, it is assumed that the intercept $\left(\beta_{i t}\right)$ is a random variable with a mean value of $\beta_{1}$ and so the intercept value for an individual firm $\beta_{1 i}=\beta_{1}+\varepsilon_{i}$ where $i=1,2,3 \ldots 10$ for equation (5), and 20 for equation (6), and $\mathcal{E}_{i}$ is a random error term with a mean value of zero and variance of $\sigma_{\varepsilon}^{2}$. Accordingly, equations (5) and (6) are represented as follows:

$$
\begin{aligned}
& G T E_{i t}^{E C}=\beta_{1}+\beta_{2} E R_{2 i t}+\beta_{3} R R_{3 i t}+\beta_{4} D Y_{4 i t}+E_{i}+U_{i t} \\
& G T E_{i t}^{L C}=\beta_{1}+\beta_{2} E R_{2 i t}+\beta_{3} R R_{3 i t}+\beta_{4} D Y_{4 i t}+E_{i}+U_{i t}
\end{aligned}
$$

These two error components are represented in a composite error term $\lambda$ such that:

$$
\lambda_{i t}=E_{i}+U_{i t}
$$

With $\varepsilon_{i}$ representing the company specific error component and $U_{i t}$ representing the combined time series and cross-section error component. Accordingly the models can be rewritten thus:

$$
\begin{aligned}
& G T E_{i t}^{E C}=\beta_{1}+\beta_{2} E R_{2 i t}+\beta_{3} R R_{3 i t}+\beta_{4} R R_{4 i t}+\lambda_{i t} \\
& G T E_{i t}^{L C}=\beta_{1}+\beta_{2} E R_{2 i t}+\beta_{3} R R_{3 i t}+\beta_{4} R R_{4 i t}+\lambda_{i t}
\end{aligned}
$$

The relevant assumptions under ECM are that $\varepsilon_{i} \sim N\left(0, \sigma_{\varepsilon}^{2}\right) ; \mu_{i t} \sim N\left(0, \sigma_{\mu}^{2}\right) ; E\left(\varepsilon_{i} \mu_{i t}\right)=0 ; E\left(\varepsilon_{i} \varepsilon_{j}\right)=$ $0 ;(i \neq j) ; E\left(\mu_{i t} \mu_{i s}\right)=E\left(\mu_{i t} \mu_{j t}\right)=E\left(\mu_{i t} \mu_{j s}\right)=0 ;(i \neq j) ;(t \neq s)$.

This means that the individual error components were not expected to be correlated with each other and were not to be auto-correlated across both cross section and time series units. It follows that in this model, $\varepsilon_{i}$ is an 
unobservable variable, and therefore

$$
E\left(\lambda_{i t}\right)=0 ; \operatorname{var}\left(\lambda_{i t}\right)=\sigma_{E}^{2}+\sigma_{\mu}^{2}
$$

Again, it indicates that ECM goes beyond ordinary pooling of time series and cross section data, and as shown above, the composite error term $\lambda_{i t}$ is homoscedastic but can be shown that $\lambda_{i t}$ and $\lambda_{i s}$ are correlated where $(t \neq s)$. The error term of a given cross sectional company at two different periods are correlated with the correlation coefficient given thus:

$$
\operatorname{corr}\left(\lambda_{i t} ; \lambda_{i s}\right)=\sigma_{E}^{2} / \sigma_{E}^{2}+\sigma_{\mu}^{2}
$$

This assumes that for any given cross sectional company, the value of the correlation between error terms at two different years remains the same no matter how far apart the time periods are (Koutsoyiannis, 2001; Gujarati \& Sangeetha, 2007). It is also assumed that the correlation structure given above remains identical for all companies.

\section{Results and Discussions}

\subsection{Test of Two Means}

Below are the results of the differences in means of pooled data for the four variables. This gives an insight in the direction or predictable behavior of the variables standing alone that would form the basis of our expectations in their causal relationships.

Table 1. Summary result of pooled means of emerging and Large companies

\begin{tabular}{ccccccc}
\hline SN & Variance & \multicolumn{2}{c}{ Emerging Companies } & \multicolumn{2}{c}{ Large companies } & \multirow{2}{*}{ Z Values } \\
\cline { 3 - 6 } & & $\mathbf{N}$ & Mean & N & Mean & Calculated \\
\hline 1 & GEC & 100 & 209864022 & 200 & 203471413 & $-8.5318 \mathrm{E}-12^{*}$ \\
2 & ER & 100 & 2.43 & 200 & 6.98 & $0.000^{*}$ \\
3 & RR & 100 & 0.657 & 200 & 0.841 & -3.078 \\
4 & DY & 100 & 0.53 & 200 & 0.0603 & 9.494 \\
\hline
\end{tabular}

Note. *Statistically significant means at 0.05 level of significance.

The descriptive data show nominal differences in the comparison between emerging and large companies about the variables studied. For retention rate and dividend yield, the null hypotheses $\left(\mu_{1}=\mu_{2}\right)$ were rejected indicating statistically significant differences between the two categories. It further demonstrates that large companies hold lesser equities than emerging companies, and this conforms with mainstream finance literature (Emekekwue, 2005; Pandey, 2005) and in line with the enterprise development continuum of Dagogo (2006). Accordingly, the dividend yield of emerging companies is significantly greater than that for large companies. This is questionable as the presumption around the application of more debt than equity implies higher shareholder's wealth. Admittedly, the expected outcome of the regression analysis is that GEC should be more elastic to retention rate in LCs than in ECs. It is however difficult to comprehend why the differences in the earnings rate of EC and LC of 2.43 and 6.98 respectively was not statistically significant. So, the nominal interpretation would be that higher earnings rate is an inducement for investors to retain their funds where the opportunity cost of capital is less. However, this line of argument is not backed by the difference in retention rate discussed above, which might be the result of other intervening variables. Suffice to state that single digit earnings rate in a high-risk business environment like Nigeria may be regarded as unattractive and so both values (irrespective of the nominal difference) belong to the same benchmark. That notwithstanding, we expect again that greater nominal value of RR for LC implies higher explained contribution of LC's ER toward GEC than that for EC.

\subsection{Panel Study with Random Effect}

The random effect result shows only RR as significant explanatory variable for changes in GEC at 0.02 percent level of significance. With probability of 0.637 and 0.3 , the respective DY and ER did not only show insignificant contribution towards changes in GEC, but are also negatively correlated to GEC such that one percent increase in DY or ER will induce 0.05 percent and 0.104 percent decrease in GEC. Whereas, one percent increase in RR will induce 0.236 percent increase in GEC. Collectively, $\mathrm{R}^{2}$ value of 0.074 was barely significant at $p=0.062$, indicating that the overall changes in independent variables are capable of explaining changes in the dependent variable if we allow up to 6.2 percent level of significance. This outcome conforms with our a prior expectation detailed earlier, although, the essence of being emerging companies increases internal capital growth 
expectations to the effect that the elasticity of one unit increase in retention rate would have been greater than unity.

Table 2. Summary statistics of panel data regression (Random Effect model) with Growth in Equity Capital (GEC) for EC as dependent variable

\begin{tabular}{lcccccc}
\hline $\mathrm{R}^{2}$ & $\mathrm{f}$-test & Sig. (f-test) & Indep. Variables & $\begin{array}{c}\text { Standardized } \\
\text { Coefficients }\end{array}$ & t-test & Sig (t-test) \\
\hline 0.074 & 2.522 & 0.062 & ER & -0.104 & -1.041 & 0.300 \\
& & & RR & 0.236 & 2.364 & 0.02 \\
DW score & & & DY & -0.050 & -0.503 & 0.616 \\
1.380 & & & & & & \\
\hline
\end{tabular}

The results from LC are as settling as those above, particularly to anyone well acquainted with the equity market. For instance, none of the independent variables significantly contributed to changes in GEC. While our $a$ priori expectation would be for mature enterprises to reduce dividend payment in order to finance growth with internal capital, in which case there should be a significant contribution of RR towards changes in GEC, this was not the case here, or so it seems, given our results. This outcome demonstrates managements' tendency towards MM argument, so that if one expects capital growth then it must emerge from outside sources rather than internal sources. Secondly, if the above postulation holds sway, that is, to increase dividend payment in preference for external capital, we expect that DY and ER will not significantly explain changes in GEC. This is not only the case in our analysis with $p$ values of 0.621 and 0.244 , but DY and ER respectively are also negatively correlated with GEC.

Table 3. Summary statistics of panel data method of regression (Random Effect model) with Growth in Equity Capital (GEC)) for LC as dependent variable

\begin{tabular}{ccccccc}
\hline $\mathrm{R}^{2}$ & \multirow{2}{*}{ f-test } & Sig. (f-test) & $\begin{array}{c}\text { Indep. } \\
\text { Variables }\end{array}$ & $\begin{array}{c}\text { Standardized } \\
\text { Coefficients }\end{array}$ & t-test & Sig (t-test) \\
\hline 0.99 & 0.653 & .509 & ER & -0.084 & -1.168 & 0.244 \\
& & & RR & 0.036 & 0.507 & 0.613 \\
DW score & & & DY & -0.036 & -0.496 & 0.621 \\
2.096 & & & & & & \\
\hline
\end{tabular}

The results of both models show that retention rate is directly related to capital growth although with LC this relationship did not turn statistically significant, further implying that LC's capital growth, if available, occurs principally with external financing. Secondly, in both models, DY and ER maintain inverse relationship with GEC, and are in both cases not found to be significant contributors to changes in GEC. Thirdly, the only significant contributor to capital growth in both models is that of RR for EC, which goes to establish the point that emerging companies increase their capital stock from internal sources more than large companies. This position is also supported by their elasticities represented by the standardized coefficients. In other words, one percent change in retention rate can cause 0.236 percent change in GEC of EC and only 0.036 percent change in GEC of LC.

\section{Conclusion}

The results did not disclose any pattern in dividend behavior of emerging or large companies that is persuasively consistent with a given dividend policy that constitutes a milestone. This tends to back the argument that dividend policy is a function of situational factors and therefore no single formula is a recipe for every situation. This falls in line with Keown's inference about the difficulty in observing any physics-like scientific design for dividend policy that will be universally consistent enough to distinguish one theory from the other. This has encouraged the application of multiple approaches as guided by individual circumstances. In furtherance of the above, the Nigerian situation is no less different from the observations elsewhere such as the study of Baker, Farrelly and Edelman (1985), which advocated for the relevance of dividend policy but not overwhelmingly so as managers have to strike a balance between opinionating and objective adherence to theories.

While this study provides intellectual insight, sharpens our contemplations on prudent utilization of earnings, 
raises our propensity to be attracted to higher earnings rate, and advances our best thinking capabilities as we stretch ourselves to seek that optimal point, empirical evidence above did not support any transcendental order in the dividend/retention dilemma. Suffice to state that we have learnt from this study that retention rate is directly related to capital growth particularly as emerging companies plan to increase their investment portfolio. Therefore, a direct relationship exists between the amount of investment and the expected rate of return, which is predictable given changes in earnings rate and dividend yield.

Finally, notwithstanding the acknowledgement that this work could be richer and more robust if we had included certain related variables in the models (e.g. leverage ratios), we are constrained to do so for the following reasons: time, finance, limited scope, and predefined research objective. These adjustments to the model will be the subject of future studies.

\section{References}

Abdou, A., \& Moshiri, S. (2012). Economic and social profiles of emerging economies. In D. Klonowski (Ed.), Private Equity in emerging markets: New Frontiers of international finance (p. 21). http://dx.doi.org/10.1057/9781137309433.0009

Adediran, S. A., \& Alade, S. O. (2013). Dividend policy and corporate performance in Nigeria. American Journal of Social and Management Sciences, 71-77.

Adelegun, O. (2001). The Impact of growth prospect, leverage and firm size on dividend behaviour of corporate firms in Nigeria. Manuscript, Department of Economics, University of Ibadan.

Adesola, W. A., \& Okwong, A. E. (2009). An empirical study of dividend policy of quoted Companies in Nigeria. Global Journal of Social Sciences, 8(1), 85-101. http://dx.doi.org/10.4314/gjss.v8i1.48907

Agundu, P. U. C., \& Dagogo, D. W. (2009). Driving Nigerian SMEs venture capital transformational financing: Focus on the Nigerian Economy. Journal of Financial Management and Analysis, 22(2).

Baker, H. K., Farrelly, G. E., \& Edelman, R. B. (1985). A survey of management views of dividend policy. Financial Management, 14(3), 196. http://dx.doi.org/10.2307/3665062

Bhattacharya, S. (1979). Imperfect information, dividend policy and "the bird in hand" fallacy. The Bell Journal of Economics, 259-270. http://dx.doi.org/10.2307/3003330

Black, F. (1976). The dividend puzzle. Journal of Portfolio Management, 2, 5-84. http://dx.doi.org/10.3905/jpm.1976.408558

Brealey, R. A. (1981). Does dividend policy matter? The revolution in corporate finance (p. 439). Oxford, Blackwell Publishers.

Brittain, J. A. (1964). The tax structure and corporate dividend policy. Economic Review, (May), $272-287$.

Charan, R., \& Tichy, N. (1998). Every business is a growth business. Toronto: Random House of Canada Limited.

Chariton, A., \& Vefeas, N. (1998). The association between operating cash flows and dividend changes: an empirical investigation. Journal of Business Finance and Accounting, 25(1)\&(2), 225-248. http://dx.doi.org/10.1111/1468-5957.00185

Cooper, D., \& Schindler, P. (2005). Business research methods (8th ed.). Boston: McGraw-Hill Irwin.

Copeland, T. E., \& Weston, J. F. (1988). Financial theory and corporate policy. Reading, Ma: Addison-Wesley.

Dagogo, D. W. (2006). Venture capital financing and enterprise development in Nigeria. unpublished $\mathrm{PhD}$ dissertation, Rivers State University of Science and Technology, Port Harcourt.

Dagogo, D. W. (2012). A review of private equity finance in Nigeria. In D. Klonowski (Ed.), Private equity in emerging Markets: New Frontiers of International Finance. New York: Palgrave MacMillan. http://dx.doi.org/10.1057/9781137309433.0033

Dagogo, D. W. (2014). Nigerian industrial development between 1943 and 2013: challenges and opportunities. International Review of Research in Emerging Markets and the Global Economy, 1(3).

Dagogo, D. W., \& Ollor, W. (2009). The effect of venture capital financing on the economic value added profile of Nigerian SMEs. African Journal of Accounting, Economics, Finance and Banking Research, 5(5).

Emekekwue, P. (2005). Corporate financial management. African Bureau of Educational Sciences, Kinshasa.

Fraser-Sampson, G. (2010). Private equity as an asset class (2nd ed.). Sussex: John-Wiley \& Son ltd. 
Gomper, P., \& Sahlman, W. (1987). Entrepreneurial finance: A casebook. New Caledonia: John Wiley and Sons Inc.

Gordon, M. J. (1959). Dividends, earnings and stock prices. Review of Economics and Statistics, 272-287.

Groh, A., \& Liechtenstein, H. (2012). Assessing country attractiveness in the venture capital and private equity landscape. In D. Klonowski (Ed.), Private equity in emerging markets: New Frontiers of International finance. New York: Palgrave MacMillan. http://dx.doi.org/10.1057/9781137309433.0010

Gujarati, D. N., \& Sangeetha. (2007). Basic Econometrics (4th ed.). New Delhi: Tata McGraw-Hill.

Jensen, M., \& Meckling, W. (1976). Theory of the firm, managerial behavior, agency cost and capital ctructure. Journal of Financial Economics, 305-360. http://dx.doi.org/10.1016/0304-405X(76)90026-X

Keown, A., Petty, J., Scott, D., \& Martin, J. (1998). Foundation of finance: the logic and practice of financial management. New Jersey: Prentice-Hall Incorporated.

Kinkki, S. (2001). Dividend puzzle - a Review of dividend theories. LTA, 1(1), 58-97.

Koutsoyiannis, A. (2001) Theory of econometrics. New York: Palgrave publishers Ltd.

Lease, R., Lewellen, W., \& Schlarbaum, G. (1976). Market segmentation: evidence on the individual investors. Financial Analysts Journal, 32, 53-60. http://dx.doi.org/10.2469/faj.v32.n5.53

Lintner, J. (1956). Distribution of income of corporations among dividends, retained earnings and taxes. American Economic Review, 97-113.

Miller, M. H., \& Scholes, M. S. (1978). Dividends and taxes. Journal of Financial Economics, $333-364$. http://dx.doi.org/10.1016/0304-405X(78)90009-0

Miller, M., \& Modigliani, F. (1961). Dividend policy, growth and the valuation of shares. Journal of Business, 34 , 411-432. http://dx.doi.org/10.1086/294442

Miller, M., \& Scholes, M. S. (1982). Dividend and taxes: some empirical evidence. Journal of Political Economy, 90, 1118-1141. http://dx.doi.org/10.1086/261114

Myers, S. (1984). Capital structure puzzle. The Journal of Finance, 575-592. http://dx.doi.org/10.2307/2327916

Nuechterlein, J. (2003). International Venture Capital, Economic Strategy and National Security. De Souza, West Press.

Nyong, M. O. (1990). Dividend Policy of Quoted Companies: a behavioral approach using recent data. Manuscript. Department of Economics, Lagos State University.

Olowe, A. (2009). Financial management: concepts, financial system and business finance. Lagos: Brierly Jones Nig Ltd.

Oyejide, A. (1976). Company dividend policy in Nigeria: An empirical analysis. Journal of Economics and Social Studies.

Pandey, I. (2005). Financial management. New Delhi: Vikas publishing.

Panneerselvam, P. (2013). Research methodology. Delhi: PHI Learning Private Limited.

Ross, S. A. (1977). The Determination of financial structure: The incentive signaling approach. Bell Journal of Economics, 8, 23-40. http://dx.doi.org/10.2307/3003485

Rozeff, M. (1982). Growth, beta and agency costs as determinants of dividend payout ratios. Journal of Financial Research, 249-259. http://dx.doi.org/10.1111/j.1475-6803.1982.tb00299.x

Smith, D. (2013). Zero-to-IPO: The essential guide to surviving start-up and cashing out, silicon valley. Cambridge Manhattan Group LLC.

Stein, H. (2001). Policy alternatives to structural adjustment in African: an introduction in Asian industrialization and Africa. Studies in policy alternative to structural adjustment. International Political Economy Series.

Stiglitz, J. (2008). Global financial crisis: causes and way forward. Paper presented to the United Nations General Assembly on the Global Repercussion of the Crisis.

Uzoaga, W. O., \& Alozienwa, J. U. (1974). Dividend policy in an era of indigenization, Nigerian. Journal of Economic and Social Studies, 16(11), 461.

Van Horne, J. (2005). Financial management and policy. Singapore: Pearson Education. 
Walter, J. (1956). Dividend policies and common stock prices. Journal of Finance, $29-41$. http://dx.doi.org/10.1111/j.1540-6261.1956.tb00684.x

Watt, R. (1973). The information content of dividends. Journal of Business, 191-211. http://dx.doi.org/10.1086/295525

Weston, F. J., \& Brigham, E. F. (2008). Managerial Finance. Hinsdale, Illinois: The Dryden Press Int. ed.

\section{Copyrights}

Copyright for this article is retained by the author(s), with first publication rights granted to the journal.

This is an open-access article distributed under the terms and conditions of the Creative Commons Attribution license (http://creativecommons.org/licenses/by/3.0/). 